\title{
Front Matter: Volume 11549
}

, "Front Matter: Volume 11549," Proc. SPIE 11549, Advanced Optical Imaging Technologies III, 1154901 (5 November 2020); doi: 10.1117/12.2585968

SPIE. Event: SPIE/COS Photonics Asia, 2020, Online Only 


\title{
PROCEEDINGS OF SPIE
}

\section{Advanced Optical Imaging Technologies III}

\author{
Xiao-Cong Yuan \\ P. Scott Carney \\ Kebin Shi \\ Editors
}

\section{1-16 October 2020 \\ Online Only, China}

\author{
Sponsored by \\ SPIE \\ COS-Chinese Optical Society
}

Cooperating Organizations

Tsinghua University (China) • Peking University (China) • University of Science and Technology of China (China) • Zhejiang University (China) • Tianjin University (China) • Beijing Institute of Technology (China) Beijing University of Posts and Telecommunications (China) • Nankai University (China) • Changchun University of Science and Technology (China) University of Shanghai for Science and Technology (China) $\bullet$ Capital Normal University (China) • Huazhong University of Science and Technology (China) • Beijing Jiaotong University (China) • China Jiliang University (China) • Shanghai Institute of Optics and Fine Mechanics, CAS (China) • Changchun Institute of Optics, Fine Mechanics and Physics, CAS (China) Institute of Semiconductors, CAS (China) • Institute of Optics and Electronics, CAS (China) • Institute of Physics, CAS (China) Shanghai Institute of Technical Physics, CAS (China) • China Instrument and Control Society (China) Japan Optical Society (Japan) • Korea Optical Society (Korea, Republic of) • Australia Optical Society (Australia) • Singapore Optical Society (Singapore) • European Optical Society

Supporting Organizations

China Association for Science and Technology (CAST) (China)

Department of Information of National Nature Science Foundation, China (NSFC) (China)

Published by

SPIE

Volume 11549 
The papers in this volume were part of the technical conference cited on the cover and title page. Papers were selected and subject to review by the editors and conference program committee. Some conference presentations may not be available for publication. Additional papers and presentation recordings may be available online in the SPIE Digital Library at SPIEDigitalLibrary.org.

The papers reflect the work and thoughts of the authors and are published herein as submitted. The publisher is not responsible for the validity of the information or for any outcomes resulting from reliance thereon.

Please use the following format to cite material from these proceedings:

Author(s), "Title of Paper," in Advanced Optical Imaging Technologies III, edited by Xiao-Cong Yuan, P. Scott Carney, Kebin Shi, Proceedings of SPIE Vol. 11549 (SPIE, Bellingham, WA, 2020) Seven-digit Article CID Number.

ISSN: 0277-786X

ISSN: 1996-756X (electronic)

ISBN: 9781510639133

ISBN: 9781510639140 (electronic)

Published by

SPIE

P.O. Box 10, Bellingham, Washington 98227-0010 USA

Telephone +1 3606763290 (Pacific Time) · Fax +1 3606471445

SPIE.org

Copyright (c) 2020, Society of Photo-Optical Instrumentation Engineers.

Copying of material in this book for internal or personal use, or for the internal or personal use of specific clients, beyond the fair use provisions granted by the U.S. Copyright Law is authorized by SPIE subject to payment of copying fees. The Transactional Reporting Service base fee for this volume is $\$ 21.00$ per article (or portion thereof), which should be paid directly to the Copyright Clearance Center (CCC), 222 Rosewood Drive, Danvers, MA 01923. Payment may also be made electronically through CCC Online at copyright.com. Other copying for republication, resale, advertising or promotion, or any form of systematic or multiple reproduction of any material in this book is prohibited except with permission in writing from the publisher. The CCC fee code is $0277-$ $786 \times / 20 / \$ 21.00$.

Printed in the United States of America by Curran Associates, Inc., under license from SPIE.

Publication of record for individual papers is online in the SPIE Digital Library.

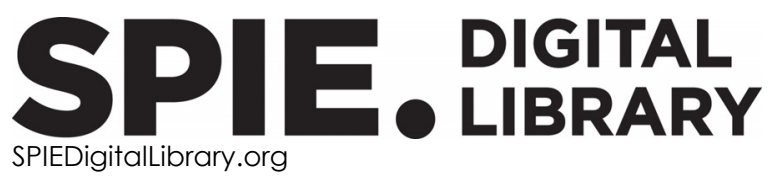

Paper Numbering: Proceedings of SPIE follow an e-First publication model. A unique citation identifier (CID) number is assigned to each article at the time of publication. Utilization of CIDs allows articles to be fully citable as soon as they are published online, and connects the same identifier to all online and print versions of the publication. SPIE uses a seven-digit CID article numbering system structured as follows:

- The first five digits correspond to the SPIE volume number.

- The last two digits indicate publication order within the volume using a Base 36 numbering system employing both numerals and letters. These two-number sets start with $00,01,02,03,04$, 05, 06, 07, 08, 09, OA, OB ... 0Z, followed by 10-1Z, 20-2Z, etc. The CID Number appears on each page of the manuscript. 


\section{Contents}

SUPER-RESOLUTION IMAGING

1154904 Lensfree super-resolved microscopy based on multi-wavelength multiplexing [11549-4]

1154907 Space-time adaptive super resolution methodology [11549-7]

\section{COMPUTATIONAL IMAGING}

$11549 \mathrm{OB} \quad$ Label-free quantitative 3D intensity diffraction tomographic imaging in high numerical aperture microscopy [11549-11]

11549 OC Optimal annular illumination pattern for Fourier ptychographic microscopy based on spectrum aliasing minimization [11549-12]

11549 OD Positional misalignment correction for Fourier ptychographic microscopy based on intensity distribution [11549-69]

11549 OE Global iterative optimization for Fourier ptychographic microscopy [11549-70]

11549 OF Improving spatial domain based image formation through compressed sensing [11549-59]

\section{WAVEFRONT ENGINEERING IN IMAGING SYSTEMS}

11549 OK Solving heterogenous region for diffuse optical tomography with a convolutional forward calculation model and the inverse neural network [11549-18]

11549 OM Gradient-based dictionary optimization for compressive spectral imaging [11549-20]

ADVANCED IMAGING TECHNIQUES AND APPLICATIONS

11549 OU Application of photoacoustic imaging for lithium metal batteries [11549-28]

\section{POSTER SESSION}

11549 OV Synthetic multi-focus optical-resolution photoacoustic microscope using multi-scale weighted gradient-based fusion [11549-29]

1154915 Optimization method for the synthetic apertures imaging system [11549-39] 
1154916 Simultaneous label-free two-photon fluorescence and second-harmonic generation microscopy for visualization of mouse pulmonary alveoli [11549-40]

1154917 Phase space retrieval and the imaging system effect [11549-41]

1154918 Coherence effect compensation in diffuser-based quantitative phase imaging [11549-42]

1154919 Anti-aliasing high resolution quantitative phase microscopy based on differential phase contrast imaging [11549-43]

11549 1A Prediction of injury depth in photothermal treatment based on the machine learning [11549-44]

11549 1C An iterative compensation solution to the transport-of-intensity equation [1 1549-46]

11549 IF Sub-diffraction dark spot localization microscopy [11549-49]

$115491 G \quad$ Research on the rough and precise correction method to the rotation axis position for optical projection image systems [11549-50]

$1154911 \quad$ Influence of substrate stiffness on the cellular mechanical properties [11549-52]

11549 1L Bayesian sparse reconstruction based on dictionary learning [11549-55]

$115491 \mathrm{M}$ Integration of time-of-flight distance measurement and optical coherence tomography for extending its operating range [11549-56]

1154910 Study on the spectral recovery effect of spectrometer based on apodization function [11549-58]

11549 IP Analysis in wavefront propagation based on ray tracing for acquisition of aberration-corrected hologram [11549-60]

$115491 Q \quad$ Research on high temperature field detection method based on energy spectrum model [11549-61]

$11549 \mathrm{IR}$ Research on temperature measurement simulation experiment based on infrared thermal image [11549-62]

11549 is The suppression of the side lobes of the fluorescence light-sheet microscopy with scanned Bessel beam by using the leaky filter [1 1549-63]

11549 IV Detection of potato early blight based on hyperspectral imaging [11549-67]

11549 IW Cryptanalysis of phase-truncated Fourier-transforms-based optical cryptosystem using an untrained neural network [11549-68] 